\title{
Determination of Mineral and Proximate Compositions of Pleurotus Ostreatus Grown on three Agrowastes
}

\author{
AGBAGWA, S. S.1; CHUKU, E. C. ${ }^{1} \&$ EMIRI, U. N. ${ }^{2}$ \\ ${ }^{1}$ Lecturer, Department of Plant Science and Biotechnology, Rivers State University, Rivers State, Nigeria \\ ${ }^{2}$ Lecturer, Department of Agricultural Education, Isaac Jasper Boro College of Education, Bayelsa State, \\ Nigeria
}

\begin{abstract}
Studies on the determination of mineral and proximate compositions of Pleurotus ostreatus grown on three agrowastes were carried out in the Department of Plant Science and Biotechnology and Dilomat Farms and Services Limited, Rivers State University. The three agrowastes (sawdust, wood ash and cassava bran) were mixed at different concentration levels and ten treatments including the combined effect and control were obtained. Proximate compositions which were moisture, ash, lipid, fibre, carbohydrate and protein were investigated. Highest values of carbohydrate $(22.61 \pm 0.00)$ and fibre (56.20 \pm 0.00$)$ were observed for sawdust and cassava bran (SCB) treatment. Although, the combined effect (CE) had highest concentrations of

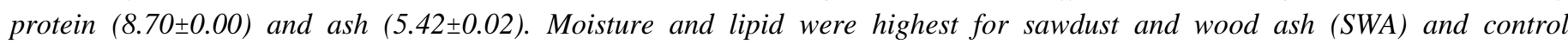
treatments respectively. Mineral analysis of harvested P. ostreatus showed that SWA treatment had highest values for Magnesium, Phosphorus, Potassium and Sodium. However, highest Calcium (25.11 \pm 0.01$)$ and Iron (3.43 \pm 0.04$)$ contents were recorded for $S C B$ and CE treatments respectively. However, sawdust and cassava bran treatments with higher concentrations recorded no harvest due to contamination. Generally, the SWA treatment had higher mineral values while CE performed better for proximate composition.
\end{abstract}

Key Words: Pleurotus ostreatus, Proximate, Mineras, Agrowastes.

\section{INTRODUCTION}

Mushrooms are naturally found growing on dead woods in the wild as saprophytes. Their cultivation imitates the conditions and situations in the wild. It involves the assemblage of the necessary materials and the creation of the enabling environment (Kuforiji $\&$ Fasidi, 2006). Members of the Pleurotus genus are distributed both in the temperate and subtropical regions. However, $P$. ostreatus is perculiar to the temperate environments because of its relatively high humidity and low temperature requirements (Trudell \& Ammirati, 2009). It has been reported to be distributed in China, USA, Germany, Korea, Switzerland, Japan and many other countries (Phillips, 2006; Bao et al., 2004).

Production of mushroom constitutes different processes such as composting, spawn production, tissue culture, bagging, inoculation, incubation, cropping and harvesting. Furthermore, the process also incorporates the use of several agrowastes, botanicals and some chemicals that support their nutrient requirements (Jonathan \& Fasidi, 2001). Oyster mushroom cultivation is faced with challenges arising from environmental and physical factors viz: temperature, $\mathrm{pH}$, light, aeration and relative humidity. The regulation of these factors at their optimum encourages the growth and development of mushroom (Fasidi et al., 2008).

Moisture, protein, fibre, ash, crude fat and carbohydrate have been shown by early researchers to be found in Pleurotus genus (Sharmila et al., 2015; Duru et al., 2019). Studies conducted by Liasu et al., (2015) implicated sodium, calcium, magnesium, potassium and manganese to be found in Pleurotus. This was also supported by the findings of Jonathan et al., (2013) as the above minerals were reported alongside others such as iron, zinc and copper. Nevertheless, there is dearth of information on the mineral and vitamin compositions of $P$. ostreatus grown on sawdust, wood ash and cassava bran. 


\section{MATERIALS AND METHODS}

\subsection{Sample Collection}

Cassava peels were collected from Omagwa community in Ikwerre Local Government Area, Rivers state. The peels were dried for one month and immediately ground into powder for further use. Sawdust and Rhizophora racemosa wood were both obtained from Timber market Mile II Diobu in Rivers State. R. racemosa woods were later burnt to collect the ash. Healthy spawns of Pleurotus ostreatus were bought from Dilomat Farms and Services Limited, Rivers State University for the study. The above materials were all conveyed to the experimental site at Dilomat farms.

\subsection{Substrate Compositions}

The materials used for the cultivation were cassava bran, wood ash and sawdust and were subjected to various mixtures leading to their respective compositions for the experiment. Three concentrations of cassava bran $(100,150$ and $200 \mathrm{~g})$ and wood ash $(0.30$, 0.60 and $1.0 \mathrm{~g})$ were varied against a constant quantity of sawdust $(1000 \mathrm{~g})$. Combined and control treatments were also set up. A total of ten treatments were used for the cultivation of $P$. ostreatus:

Sawdust and wood ash (SWA): SWA1, SWA2, SWA3

Sawdust and cassava bran (SCB): SCB1, SCB2, SCB3

Combined effect (CE): CE1, CE2, CE3

Control (C)

The numbers attached to the abbreviated formulation indicate the concentration levels of wood ash and cassava bran in an increasing order.

\subsection{Cultivation Studies}

The cultivation methods of Chinda \& Chinda, (2009) were adopted for this research. The different substrate compositions were composted for 40days. At the end of composting, the substrates were immediately bagged and sterilized through pasteurization at $100^{\circ} \mathrm{C}$ for 6hours. After the sterilized bags cooled, they were inoculated with $74.99 \pm 21.66 \mathrm{~g}$ of spawn and incubated at room temperature $\left(25 \pm 3^{0} \mathrm{C}\right)$ for 38 days. Fully colonized bags were immediately cropped and watered for 3 days. Fruiting bodies were later harvested and subjected to various studies.

\subsection{Nutrient Composition Studies}

The determination of proximate and mineral contents of harvested $P$. ostreatus mushroom from the various substrate composition were done using the methods earlier described by AOAC, (2005) and (1990). Data obtained were all subjected to statistical analysis.

\section{RESULTS}

Table 1: Effect of different substrate compositions on the proximate composition of $P$. ostreatus (\%)

\begin{tabular}{|l|l|l|l|l|l|l|}
\hline $\begin{array}{l}\text { Sub. } \\
\text { Comp. }\end{array}$ & \multicolumn{1}{|c|}{ Moisture } & \multicolumn{1}{|c|}{ Ash } & Fipre & CHO & Protein \\
\hline C & $85.51 \pm 0.01^{\mathrm{f}}$ & $1.04 \pm 0.00^{\mathrm{ab}}$ & $5.22 \pm 0.03^{\mathrm{g}}$ & $0.93 \pm 0.01^{\mathrm{a}}$ & $4.04 \pm 0.06^{\mathrm{a}}$ & $3.37 \pm 0.17^{\mathrm{c}}$ \\
\hline CE1 & $61.52 \pm 0.0^{\mathrm{c}}$ & $5.21 \pm 0.01^{\mathrm{c}}$ & $1.50 \pm 0.00^{\mathrm{b}}$ & $14.53 \pm 0.04^{\mathrm{c}}$ & $9.11 \pm 0.01^{\mathrm{b}}$ & $8.22 \pm 0.02^{\mathrm{g}}$ \\
\hline CE2 & $62.52 \pm 0.02^{\mathrm{d}}$ & $5.32 \pm 0.02^{\mathrm{d}}$ & $1.56 \pm 0.02^{\mathrm{c}}$ & $15.23 \pm 0.04^{\mathrm{d}}$ & $10.03 \pm 0.04^{\mathrm{b}}$ & $5.44 \pm 0.01^{\mathrm{f}}$ \\
\hline CE3 & $60.61 \pm 0.01^{\mathrm{b}}$ & $5.42 \pm 0.02^{\mathrm{e}}$ & $1.61 \pm 0.01^{\mathrm{c}}$ & $14.24 \pm 0.05^{\mathrm{b}}$ & $9.52 \pm 0.02^{\mathrm{b}}$ & $8.70 \pm 0.00^{\mathrm{h}}$ \\
& & & & & & \\
\hline
\end{tabular}


International Journal of Research in Agriculture, Biology \& Environment (ijagri), Vol. 1(2), Jul-Sep-2020

\begin{tabular}{|l|c|c|c|c|c|c|}
\hline SCB1 & $10.22 \pm 0.03^{\mathrm{a}}$ & $5.23 \pm 0.04^{\mathrm{c}}$ & $0.57 \pm 0.02^{\mathrm{a}}$ & $56.20 \pm 0.00^{\mathrm{e}}$ & $22.61 \pm 0.00^{\mathrm{c}}$ & $5.24 \pm 0.01^{\mathrm{e}}$ \\
\hline SCB2 & - & - & - & - & - & - \\
\hline SCB3 & - & - & - & - & - \\
\hline SWA1 & $84.64 \pm 0.06^{\mathrm{e}}$ & $1.06 \pm 0.01^{\mathrm{b}}$ & $5.11 \pm 0.01^{\mathrm{f}}$ & $0.87 \pm 0.00^{\mathrm{a}}$ & $4.12 \pm 0.03^{\mathrm{a}}$ & $4.26 \pm 0.01^{\mathrm{b}}$ \\
\hline SWA2 & $86.51 \pm 0.02^{\mathrm{g}}$ & $1.01 \pm 0.02^{\mathrm{ab}}$ & $5.02 \pm 0.03^{\mathrm{e}}$ & $0.86 \pm 0.02^{\mathrm{a}}$ & $3.81 \pm 0.02^{\mathrm{a}}$ & $2.86 \pm 0.01^{\mathrm{d}}$ \\
\hline SWA3 & $87.03 \pm 0.04^{\mathrm{h}}$ & $1.00 \pm 0.00^{\mathrm{a}}$ & $4.91 \pm 0.02^{\mathrm{d}}$ & $0.86 \pm 0.00^{\mathrm{a}}$ & $18.83 \pm 21.17^{\mathrm{bc}}$ & $2.43 \pm 0.01^{\mathrm{a}}$ \\
\end{tabular}

*Means with the same superscript across the column are not significantly different $(\mathrm{p} \leq 0.05)$

- = no harvest, Sub. Comp.=Substrate compositions and $\mathrm{CHO}=$ Carbohydrate

Table 2: Effect of different substrate compositions on the mineral composition of $P$. ostreatus (mg/100g)

\begin{tabular}{|l|c|c|c|c|c|c|}
\hline $\begin{array}{l}\text { Sub. } \\
\text { Comp. }\end{array}$ & Ca & Fe & Mg & P & K & Na \\
\hline C & $20.50 \pm 0.00^{\mathrm{e}}$ & $2.51 \pm 0.02^{\mathrm{c}}$ & $11.21 \pm 0.02^{\mathrm{e}}$ & $19.52 \pm 0.02^{\mathrm{e}}$ & $18.63 \pm 0.04^{\mathrm{e}}$ & $21.22 \pm 0.02^{\mathrm{b}}$ \\
\hline CE1 & $15.00 \pm 0.00^{\mathrm{a}}$ & $3.33 \pm 0.04^{\mathrm{g}}$ & $10.41 \pm 0.02^{\mathrm{c}}$ & $11.62 \pm 0.02^{\mathrm{b}}$ & $13.80 \pm 0.00^{\mathrm{c}}$ & $14.52 \pm 0.03^{\mathrm{b}}$ \\
\hline CE2 & $15.51 \pm 0.02^{\mathrm{b}}$ & $3.22 \pm 0.02^{\mathrm{f}}$ & $10.20 \pm 0.00^{\mathrm{b}}$ & $11.43 \pm 0.04^{\mathrm{a}}$ & $13.61 \pm 0.01^{\mathrm{b}}$ & $14.11 \pm 0.02^{\mathrm{b}}$ \\
\hline CE3 & $16.01 \pm 0.01^{\mathrm{c}}$ & $3.43 \pm 0.04^{\mathrm{h}}$ & $10.82 \pm 0.03^{\mathrm{d}}$ & $11.81 \pm 0.01^{\mathrm{c}}$ & $14.03 \pm 0.04^{\mathrm{d}}$ & $14.10 \pm 0.00^{\mathrm{b}}$ \\
\hline SCB1 & $25.11 \pm 0.01^{\mathrm{h}}$ & $2.12 \pm 0.03^{\mathrm{a}}$ & $3.01 \pm 0.02^{\mathrm{a}}$ & $13.51 \pm 0.01^{\mathrm{d}}$ & $12.02 \pm 0.03^{\mathrm{a}}$ & $1.02 \pm 0.03^{\mathrm{a}}$ \\
\hline SCB2 & - & - & - & - & & - \\
\hline SCB3 & - & - & - & - & & \\
\hline SWA1 & $21.21 \pm 0.02^{\mathrm{f}}$ & $3.02 \pm 0.02^{\mathrm{e}}$ & $11.42 \pm 0.03^{\mathrm{f}}$ & $19.60 \pm 0.00^{\mathrm{f}}$ & $18.70 \pm 0.00^{\mathrm{f}}$ & $14.01 \pm 16.28^{\mathrm{b}}$ \\
\hline SWA2 & $20.12 \pm 0.03^{\mathrm{d}}$ & $2.41 \pm 0.00^{\mathrm{b}}$ & $11.42 \pm 0.02^{\mathrm{f}}$ & $19.60 \pm 0.00^{\mathrm{f}}$ & $18.80 \pm 0.00^{\mathrm{g}}$ & $22.10 \pm 0.00^{\mathrm{b}}$ \\
\hline SWA3 & $22.13 \pm 0.04^{\mathrm{g}}$ & $2.81 \pm 0.02^{\mathrm{d}}$ & $11.64 \pm 0.05^{\mathrm{g}}$ & $20.02 \pm 0.03^{\mathrm{g}}$ & $19.51 \pm 0.02^{\mathrm{h}}$ & $22.61 \pm 0.01^{\mathrm{b}}$ \\
\hline & & & & & & \\
\hline
\end{tabular}

*Means with the same superscript across the column are not significantly different $(\mathrm{p} \leq 0.05)$

- = no harvest and Sub. Comp.=Substrate compositions 
Result of the effect of substrate compositions on the proximate composition of cultivated P. ostreatus as shown in Table 1, revealed the presence of moisture, ash, lipid, carbohydrate and protein in all the substrates formulated for the cultivation of $P$. ostreatus. However, highest values of $87.03 \pm 0.04,5.42 \pm 0.02,5.22 \pm 003,56.20 \pm 0.00,22.61 \pm 0.00$ and $8.70 \pm 0.00$ were recorded for SWA3, CE3, C, SCB1, SCB1 and CE3 for the proximate compositions respectively. Also, lowest proximate values (10.22 \pm 0.03 , $1.00 \pm 0.00,0.57 \pm 0.02,0.86 \pm 0.02,3.81 \pm 0.02$ and $2.43 \pm 0.01)$ were recorded for SCB1, SWA3, SCB1, SWA2\&3, SWA2 and SWA3 for the assessed parameters respectively. Treatments SCB2 and SCB3 did not record any fruit in this experiment.

The effect of different substrate compositions on the mineral composition of $P$. ostreatus presented in Table 2 , showed the availability of calcium, iron, magnesium, phosphorus, potassium and sodium. It was also observed that the highest values $(25.11 \pm 0.01,3.43 \pm 0.04,11.64 \pm 0.05,20.02 \pm 0.03,19.51 \pm 0.02$ and 22.61 \pm 0.01$)$ were recorded for SCB1, CE3, SWA3, SWA3, SWA3 and SWA3 for the above outlined mineral parameters respectively, while the lowest concentrations (15.00 \pm 0.00 , $2.12 \pm 0.03,3.01 \pm 0.02,11.43 \pm 0.04,12.02 \pm 0.03$ and 1.02 \pm 0.03 ) were recorded for CE1, SCB1, SCB1, CE2, SCB1 and SCB1 for the minerals respectively. There were no results for treatments SCB2 and SCB3 because of microbial contaminations.

\section{DISCUSSION}

The proximate result of cultivated $P$. ostreatus subjected to ANOVA test has shown that there is significant difference in the effect of different substrate compositions for moisture, ash, lipid, fibre, carbohydrate and protein in the cultivated $P$. ostreatus at $\mathrm{p} \leq 0.05$. Nevertheless, the combined effect (CE) recorded higher values than the other treatments. More so, the high carbohydrate increase in SCB1 in this study could be related to the great availability of carbohydrate in the cassava bran substrates used for the cultivation of $P$. ostreatus.

The results of this study are lower than those reported by Ahmed et al., (2016) for P. ostreatus cultivated on sawdust supplemented with wheat bran and lime. However, the result of the current study agrees with that of Iqbal et al., (2016) as they researched on the cultivation of $P$. florida on wheat, rice, sugarcane, maize and sorghum substrates. Familoni et al., (2018) reported lower moisture content and higher values of every other parameter assessed in this study for Pleurotus species cultivated on different plant wood dusts. The present study further agrees with the result presented by Duru et al., (2019) for P. ostreatus. This was also supported by the findings of Sharmila et al., (2015).

Nwoko et al., (2017) reported higher values of protein and carbohydrate than those found in this study, although lower values were reported for the other parameters in this study. Oyetayo \& Ariyo, (2013) reported lower values for moisture, ash, fibre and lipid for $P$. ostreatus compared to those found in this study. However, higher values of carbohydrate and protein were also recorded compared to their equivalents in this study. Similar condition was reported by Chirinang $\&$ Intarapichet, (2009) for $P$. ostreatus.

The carbohydrate and protein values reported for $P$. pulmonarius by Islam et al., (2017) are higher than those found in this study. Notwithstanding, Adebola et al., (2018) reported lower proximate values for $P$. ostreatus cultivated on different sawdust substrate.

The importance of these parameters cannot be overlooked in the day to day activities of man as they support in the provision of energy (carbohydrate and lipid), amino acid (protein) and reduction of cholesterol (fibre) (Campos-Vega et al., 2010; Marten et al., 2017).

The present study also showed that there is significant difference in the effect of different substrate compositions on calcium, iron, magnesium, phosphorus, potassium and sodium in the cultivated $P$. ostreatus at $\mathrm{p} \leq 0.05$. Generally, SWA treatment performed better in terms of mineral composition than any other treatment. The increased mineral values in this study could be associated with the high contents of these same minerals in the agrowastes used in the study.

The mineral compositions in this current study were higher than those reported by Ahmed et al., (2016) for several species of Pleurotus including P. ostreatus. Iqbal et al., (2016) also reported lower mineral values for $P$. florida compared to those recorded in this study. Jonathan et al., (2013) further reported similar lower values for all the mineral parameters assessed in this study for $P$. pulmonarius cultivated on various agrowastes excluding wood ash and cassava bran.

However, the mineral composition of this current study is in line with those reported by Adebayo et al., (2014b) for P. ostreatus. The study of Duru et al., (2019) implicated higher contents of calcium for P. ostreatus than its equivalent in this study. However, other mineral parameters assessed in this study are higher than those they reported. In addition, Nwoko et al., (2017) reported lower values of $P$. pulmonarius than those recorded in this study. Oyetayo \& Ariyo, (2013) reported lower values of mineral for $P$. ostreatus than those found in this study.

Mineral elements have been revealed by several authors and literatures to assist and support physiological, biochemical and metabolic processes. More so, calcium aids strong bone and iron a very important content of the blood system (Piska et al., 2017; Idu \& Onyibe, 2007). 


\section{CONCLUSION}

The various agrowastes employed in this study influenced the mineral and proximate compositions of cultivated $P$. ostreatus. Sawdust and wood ash treatments had more mineral contents whereas highest values for proximate composition were observed for the combined effect treatment.

\section{REFRENCES}

Adebola, M. O., Yusuf, S., Bello, T. S., \& Kalesanwo, A. O. (2018). Effects of different plant sawdust substrates on the cultivation of Plerotus ostreatus. Niger J. Mycol., 10:116-128.

Ahmed, M., Abdullah, N., \& Nuruddin, M. M. (2016). Yield and nutritional composition of oyster mushrooms: An alternative nutritional source for rural people. Sains Malaysiana, 45(11): 1609-1615.

AOAC, (1990). Official methods of analysis of AOAC international. $15^{\text {th }}$ edition. Association of official analytical chemists, Washington, D.C., USA.

AOAC, (2005). Official methods of analysis of AOAC international. $18^{\text {th }}$ edition. Association of official analytical chemists, Washington, D.C., USA.

Bao, D., Kinugasa, S., \& Kitamoto, Y. (2004). The biological species of oyster mushrooms (Pleurotus spp) from Asia based on mating compatibility test. J. Wood Sci., 50: 162-168.

Campos-Vega, R., Loarca-Pina, G., \& Oomah, B. D. (2010). Minor components of pulses and their potential impact on human health. Food Res. Int., 43:461-482.

Chinda, M. M., \& Chinda, F. (2007). Mushroom cultivation for health and wealth. Image and Media Associates Ltd., pp104.

Chirinang, P., \& Intarapichet, K. (2009). Amino acids and antioxidant properties of the oyster mushrooms, Pleurotus ostreatus and P. sajor-caju. Science Asia, 35: 326-331.

Duru, M., Eboagwu, I., Kalu, W., \& Odika, P. (2019). Nutritional, anti-nutritional and biochemical studies on the oyster mushroom, Pleurotus ostreatus. E. C. Nutrition, 14(1): 36-59.

Familoni, T. V., Ogidi, C. O., Akinyele, B. J., \& Onifade, A. K. (2018). Evaluation of yield, biological efficiency and proximate composition of Pleurotus species cultivated on different wood dusts. Czech Mycology, 70(1):33-45.

Fasidi, I. O., Kadiri, M., Jonathan, S. G., Adenipekun, C. O., \& Kuforiji O. O. (2008). Cultivtaion of edible tropical mushrooms. Ibadan University Press, pp77.

Idu, M., \& Onyibe, H. I. (2007). Medicinal plants of Edo State, Nigeria. Research J. of Med. Plants, 1:32-41.

Iqbal, B., Khan, H., Khan, I., Shan, B., Naeem, A., Ullah, W., Khan, N., Adnan, M., Shah, S. R. A., Junaid, K., Ahmed, N., \& Iqbal, M. (2016). Substrates evaluation for the quality, production and growth of oyster mushroom (Pleurotus florida Cetto). J. of Entomology and Zoology Studies, 4(3): 98-107.

Islam, T., Zakaria, Z., Hamidin, N., \& Ishak, M. A. (2017). Analysis of major nutritional components of Pleurotus pulmonarius during cultivation in different indoor environmental conditions on sawdust. Turkish J. of Agric. Food Sci. \& Technol., 5(3): 239-246.

Jonathan, S. G., Nwokolo, V. M., \& Ekpo, E. N. (2013). Yield performance of Pleurotus pulmonarius (Freis) Quelet, cultivated on different agro-forest wastes in Nigeria. World Rural Observations, 5(1): 22-30.

Jonathan, S. G., \& Fasidi, I. O. (2001). Effect of carbon, nitrogen and mineral sources on growth of Psathyerella afroumbonata (Pegler), a Nigerian mushroom. Food Chem., 72: 479-483.

Kuforiji, O. O., \& Fasidi, I. O. (2006). Vegetative growth requirements of V. volvacea, a Nigerian mushroom. J. Appl. Sci., 9(2): 6309-6315.

Liasu, M. O., Adeeyo, A. O., Olaosun, O., \& Oyedokun, R. O. (2015). Pleurotus pulmonarius cultivation on amended palm press fibre waste. Afri. J. of Biotech., 14(19): 1624-1631.

Marten, L. G., Nilsen, M. M., \& Provan, F. (2017). Pea hulfibre: Novel and sustainable fibre with important health and fractional properties. E. C. Nutrition, 10(4):139-148. 
Nwoko, M. C., Onyeizu, U. R., Okwulehie, I. C., \& Ukoima, H. N. (2017). Nutritional and bioactive compounds evaluation of Pleurotus pulmonarius (Freis) quell fruit bodies grown on different wood logs in Abia state, Nigeria. J. Pet. Environ. Biotechnol., 7: 325.

Oyetayo, V. O., \& Ariyo, O. O. (2013). Micro and macro nutrient properties of Pleurotus ostreatus (Jacq:Fries) cultivated on different wood substrate. Jordan J. of Biol. Sci., 6(3):223-266.

Phillips, R. (2006). Mushrooms. McMilan Pub., pp266.

Piska, K., Sulkowska-Ziaja, K., \& Muszynska, B. (2007). Edible mushroom Pleurotus ostreatus (Oyster mushroom)- its dietary significance and biological activity. Acta Sci. Pol. Hortorum Cultus, 16(1): 151-161.

Sharmila, S., Rebecca, J. L., Tissopi, T., \& Kowsalya, E. (2015). Effect of substrates on the cultivation of Pleurotus ostreatus and its nutritional analysis. Der Pharmacia Lettre, 7(8): 193-196.

Trudell, S., \& Ammirati, J. (2009). Mushrooms of the pacific northwest. Timber press, Poortland, pp 134. 